\title{
GEOGRAPHICAL INFORMATION SYSTEMS AS A TOOL TO ASSIST THE ELECTRICITY DISTRIBUTION NETWORKS PLANNING
}

\author{
- Mario Andrés Mejía Alzate ${ }^{1}$ \\ Joel David Melo Trujillo ${ }^{2}$ \\ ANTONIO PADILHA FELTRIN ${ }^{3}$ \\ CARMEN CECILIA SÁNChEZ Zuleta ${ }^{4}$ \\ JUAN PABLO FERNÁNDEZ GUTIÉRREZ ${ }^{5}$
}

\section{ABSTRACT}

In recent years, the population growth in urban areas of Latin American cities has resulted in an increase in demand for electricity in a dispersed manner, bringing challenges to the planning of distribution systems to supply this demand. In addition, incentives for the installation of distributed generation make it necessary to carry out analyzes with a spatial perspective to determine the places of impact in the electricity distribution networks. Geographic information systems are computational tools that allow the processing of data with geographic reference. These systems can collaborate in the visualization of the socioeconomic characteristics and the variables distributed in the zone of study, being able to provide information to the distribution planners. This work shows computational tools that will help distribution utilities, using techniques available in geographic information systems to characterize the local factors in concession zone of the distribution utilities.

KEYWORDS: Planning of the Distribution System, Geographic Information Systems, Geo processing, Spatial Analysis, and Socioeconomic Characteristics.

1 Ingeniero electricista, Magíster en ingeniería eléctrica, doctorando en ingeniería eléctrica. Estudiante investigador Universidad Estadual Paulista - UNESP, SP, Brasil.

2 Ingeniero electricista, Magíster en ingeniería eléctrica, Doctor en ingeniería eléctrica. Profesor Adjunto Universidad Federal do ABC - UFABC, SP, Brasil.

3 Ingeniero electricista, Magister en ingeniería eléctrica, Doctor en ingeniería eléctrica. Profesor titular Universidad Estadual Paulista - UNESP, SP, Brasil. Profesor visitante Universidad Federal do ABC - UFABC, SP, Brasil.

4 Matemática, Magíster en Matemáticas. Profesora vinculada Universidad de Medellín- U de M. Medellín, Colombia.

5 Matemático, Magíster en Matemáticas. Profesor vinculado Universidad de Medellín- U de M. Medellín, Colombia.

Autor de correspondencia: Mejía Alzate, M.A. (Mario Andrés): Rua caruaru 101, apto 7, Ilha solteira - São Paulo, Brasil. C.P.: 15385-000. Tel.: (18) 3743-1000 - Ramales: 1622 - 1626. Correo electrónico: maanmejia@utp.edu.co, marioandretty_17@hotmail.com
Historia del artículo:

Artículo recibido: 19-VII-2017/ Aprobado: 30-IV-2018

Disponible online: 10 de mayo de 2018

Discusión abierta hasta octubre de 2019 


\section{SISTEMAS DE INFORMACIÓN GEOGRÁFICA COMO HERRAMIENTA DE AYUDA A LA PLANIFICACIÓN DE LAS REDES DE DISTRIBUCIÓN DE ENERGÍA ELÉCTRICA}

\section{RESUMEN}

En los últimos años, el crecimiento de la población en las áreas urbanas de las ciudades de Latinoamérica ha causado aumento en la demanda eléctrica de manera dispersa, trayendo desafíos a la planificación de los sistemas de distribución, para satisfacer esta demanda. Además, los incentivos para instalación de generación distribuida hacen necesario realizar análisis con perspectiva espacial para determinar los lugares de mayor impacto en las redes de distribución eléctrica. Los sistemas de información geográfica son herramientas computacionales que permiten el procesamiento de datos con referencia geográfica. Estos sistemas pueden colaborar en la visualización de las características socioeconómicas y las variables distribuidas en la zona de estudio, proporcionando informaciones a los planificadores de distribución. Este trabajo muestra herramientas computacionales que ayudarán a las empresas de distribución, utilizando técnicas disponibles en sistemas de información geográfica para caracterizar las particularidades locales, en la zona de concesión, de las empresas de distribución.

PALABRAS CLAVES: Planificación del Sistema de Distribución, Sistemas de Información Geográfica, Geo procesamiento, Análisis Espacial, Características Socioeconómicas.

\section{SISTEMAS DE INFORMAÇÃO GEOGRÁFICA COMO FERRAMENTA DE AUXÍLIO AO PLANEJAMENTO DAS REDES DE DISTRIBUIÇÃO DE ENERGIA ELÉTRICA}

\section{RESUMO}

Nos últimos anos, o crescimento da população nas áreas urbanas das cidades de Latino América, resultou no aumento da demanda elétrica de forma dispersa, trazendo desafios ao planejamento de sistemas de distribuição para atender essa demanda. Além disso, incentivos para a instalação de geração distribuída tornam necessária a realização de análises com caráter espacial para determinar os locais de maior impacto nas redes de distribuição de energia. Os sistemas de informação geográfica são ferramentas computacionais que permitem o processamento de dados com referência geográfica. Esses sistemas podem colaborar na visualização das características socioeconômicas e das variáveis distribuídas na zona de estudo, podendo fornecer informações aos planejadores de distribuição. Este trabalho mostra ferramentas computacionais que ajudarão os serviços de distribuição, usando técnicas disponíveis em sistemas de informação geográfica para caracterizar os fatores locais da zona de concessão dos serviços de distribuição.

PALAVRAS CHAVES: Planejamento do Sistema de Distribuição, Sistemas de Informação Geográfica, Geoprocessamento, Análise Espacial, Caraterísticas socioeconômico.

\section{INTRODUCTION}

The main objective of the expansion planning of the distribution networks is determining the topological, structural and physical conditions necessary, for the system can supply the electric power demand, within a defined time horizon (GONEN, 2014). In recent years, to meet this objective has become a major challenge for planning departments of distribution utilities because of the various changes 
that are occurring in the electricity sector (WEI, et al., 2017; LEOU, TENG and SU, 2015).

The expansion of the distribution networks is limited by available areas in the urban zone, for the construction of new electrical facilities (substations, transformer and distribution lines). In addition, there are environmental laws that prohibit the construction of these electrical installations in sectors of the metropolitan area (GONEN, 2014; SHU, et al., 2012).

The changes in the habits of energy consumption are one of the factors that influences in the electrical demand growth in urban zones. In recent years, a wide range of home appliances has been offered to improve the comfort in the home in Latin American cities, such as clothes dryers, air conditioner, machines for washing dishes, electric stoves, among others, consequently, changing the habits of energy consumption. The massive purchase of these electrical appliances, considerably affects the energy demand of the residential sector (MEJÍA, MELO, ZAMBRANO and PADILHA, 2016).

On the other hand, there are several countries such as Italy, Australia, Japan, and Spain, where the government promotes and encourages the installation of photovoltaic panels to supply the electrical demand of residential users. This type of energy generation is considered as a clean energy alternative (SILVA LORA and ADDAD, 2006). The installation of these generation sources can reduce the electricity demand of the distribution network in some periods of the day (HAMMONS et al., 2000; RENEWABLES 2015 GLOBAL STATUS REPORT, 2015; ZAHEDI, 2010). However, this may bring some operational problems, in cases of a high insertion in the distribution networks (HO and KIM, 2013; WATSON et al., 2016).

In this way, the determination of the geographical location of the construction of new electrical facilities that can supply the electrical demand in the locals with higher growth, and the identification of the elements of the electricity grid that will receive intermittent sources is one of the great challenges that are presented in the planning of the distribution network.

The Geographic Information Systems (GIS) are computational tools thatallow the association of georeferenced databases with digital maps, to facilitate the visualization of geographical characteristics of an area of interest (CÂMARA, 2004). In addition, these tools allow the identification and analysis of spatial patterns to determine and compare characteristics typical of a region, resulting in a very useful tool for solving complex problems of expansion planning in utilities (GUTIÉRREZ y GOULD 1994; MIRANDA, 2015; SILVA, 2003).

The GIS are composed for tools of data analysis and optimization, to solve problems of diverse fields of the engineering (GUTIÉRREZ and GOULD 1994). However, these tools do not solve all the problems of the distribution utilities, requiring the creation of new libraries and / or the adaptation of existing libraries to solve specific problems that are presented in the expansion planning of distribution network.

The GIS is a new technology in several planning departments of distribution utilities on Latin American cities (QUIROS-TORTOS, VALVERDE, ARGÜELLO and OCHOA, 2017). For the application in the planning studies, all information must be geo referenced, which is a difficulty for the use of GIS in some utilities. In general, the time to collect this information, construction of adequate databases and their updating is high (ARANEDA, 2002). On the other hand, some distribution utilities have digitized the geographic location of the network. This also hinders the use of GIS tools (KAGAN et. al., 2013).

The spatial analysis tools available in GIS have been used in different planning studies of the electric power distribution network in Latin American cities. For example, in the work developed by Mejia, Melo, Zambrano and Padilha (2016), were used tools available in a commercial GIS to estimate the market potential of household appliances with high electrical consumption. Villavicencio, Melo and Padilha (2015), used the GIS tools to estimate the photovoltaic potential due to the installation of 
photovoltaic panels on the roofs of the residential area. In the same way, GIS tools have been used to implement optimization algorithms to consider spatial restrictions in the construction of new electrical facilities in the urban area (SHU, et al., 2012), to connect new loads to existing networks (MELO, ZAMBRANO-ASANZA and PADILHAFELTRIN, 2017; QUIROS-TORTOS, VALVERDE, ARGÜELLO and OCHOA, 2017), among others.

Therefore, despite the difficulties that arise for some distribution utilities, the GIS tools are very useful, and serve as support to develop the expansion planning studies, contributing with the geographic identification of strategic places for the construction of new electrical facilities, considering restrictions of the urban area and changes in the habits of consumption. In this paper, we will be shown how the GIS tools can help in the planning process of distribution networks.

This paper has been structured in 3 sections. In the first section, the models available in the GIS tools for the planning of the electrical networks will be explained, which were grouped in data analysis techniques and optimization in the location of facilities. In the second section, the application of GIS tools will be shown in different case studies in Latin American cities. Discussions on the difficulties, new challenges and recommendations for the use of GIS tools are presented in section 3 .

\section{MODELS OF ANALYSIS AVAILABLE IN GIS TOOLS FOR ELECTRICAL}

\section{NETWORK PLANNING}

The Study of social-cultural, economic and environmental aspects involved in the rise of markets that lead to an increase in the demand of energy, both in emerging sectors of the city, and those already established, is a factor related to the geographical location of the agents, and they constitute essential aspects for the specification of the models to implement. In these circumstances, the techniques of spatial data analysis become themselves an essential tool in the study of these dependencies; and with them, the geographic information systems (GIS) also become the ideal way and tool to carry out this kind of analysis.

Geographic information systems (GIS) are described by some authors as the tool in which georeferencing is supported, and which allows storing, visualizing, analyzing, questioning and interpreting geographically related data, in such a way that patterns, Relationships and possible trends that exist between them, can be unveiled.

According to Rubio Barroso and Gutierrez (1997) in a GIS two components can be identified as:

A data Model. In this one, the characteristics of geographical objects are stored, alongside the coordinates and the relationships between the different objects. The GIS counts fundamentally with three data models:

The Topological vector, is the most classic, its basic entities are dots, lines and polygons. Although it is a flexible model, it keeps the entities and their relationships, which results in a computational cost.

Non-Topological Vector, in this case the entities are the only ones stored, however, this aspect limits the kind of applications that can be performed with

Raster, this is a data model more oriented to continuous character problems. It consists in dividing the space in a square grid of any desired size, and assigning a value to each one of them. As a strength, it is able to be approximated to the variable as much as one wants, but its weakness is located in the fact that the High accuracy increases the requirement of space on the disk, occupying more space than the vector.

A collection of functions. This group of functions enables obtaining the desired information based on the database. This information, which is going to offer a response to the concerns of the investigator would be presented trough lists and images such as maps. 
The mentioned functions on the previous paragraph involve elements of spatial analysis that range from the spatial exploration of the data, to the implementation and development of models of dependence and spatial optimization. There are varied tools on the medium dedicated specifically to systems of geo-referenced information (GIS), some of them of free distribution, as GEODA, others with a cost to the user, as the Arcgis. Additionally, multiple tools of statistic use, both of free distribution and with a cost, have implemented libraries that allow the users implementing developments and georeferenced analysis, some of them are: R, Python SAS and MATLAB.

\section{Exploratory spatial data analysis. ESDA}

When there's a desire of developing a spatial analysis to a set of data, before proceeding to implement the models, an exploratory spatial data analysis must be done (ESDA). The ESDA can be understood as a set of techniques that describe and visualize the spatial distributions of variables and detect atypical locations such as the well-known "outlier". It's useful to discover existing spatial association schemes, detecting clusters (the socalled hot-spots and cold-spots too), besides, they suggest spatial structures or other forms of spatial heterogeneity. The ESDA is an essentially graphic analysis, with a completely descriptive character of the variables, which can also be used to identify systematic relationships between the variables when there's no clear expectations over the nature of these relationships.

The visualization of the spatial data that are used in an ESDA implements some cartographic tools, which offer different ways of presenting the maps and the link between the maps and the different statistical graphics. In chart 1 there's a resume of the most useful graphical methods, frequently used in an ESDA process and their respective purpose as well.
TABLE 1. EXPLORATORY SPATIAL DATA ANALYSIS ESDA TECHNIQUES

\begin{tabular}{|c|c|}
\hline Purpose & Exploratory Technique \\
\hline $\begin{array}{l}\text { Spatial Distribution } \\
\text { Visualization }\end{array}$ & $\begin{array}{l}\text { - } \quad \text { Box map diagram } \\
\text { - } \quad \text { Existogram } \\
\text { - Variance Analysis }\end{array}$ \\
\hline $\begin{array}{c}\text { Global Spatial Association } \\
\text { Visualization }\end{array}$ & $\begin{array}{l}\text { - Spatial Delay } \\
\text { Graphics } \\
\text { - } \quad \text { Moran's Scatterplot } \\
\text { and map }\end{array}$ \\
\hline $\begin{array}{c}\text { Local Spatial Association } \\
\text { Visualization }\end{array}$ & $\begin{array}{l}\text { - } \quad \text { LISA map } \\
\text { - } \quad \text { LISA box map } \\
\text { - } \quad \text { Outliers on Moran's } \\
\quad \text { Scatterplot }\end{array}$ \\
\hline $\begin{array}{l}\text { Multi-variant Spatial } \\
\text { Association }\end{array}$ & $\begin{array}{l}\text { - } \quad \text { Moran's multi- } \\
\text { variant scatter plot }\end{array}$ \\
\hline Spatial Heterogeneity & $\begin{array}{l}\text { - } \begin{array}{l}\text { Frequencies } \\
\text { Histogram map }\end{array} \\
\text { - Scatter plot }\end{array}$ \\
\hline \multicolumn{2}{|c|}{ Source: Acevedo \& Velázquez 2008.} \\
\hline
\end{tabular}

Some of the most used diagrams are: Box map diagram, this graphic highlights those regions that present outlier values of the target variable, it is accompanied by a box-and-whisker plot where said atypical values can also be seen. The box map, has the purpose of identifying outlier regions. In this case the objective is to identify groups of regions with similar characteristics determined by the values of the target variable; additionally, the regions are classified in criterion groups by percentiles, deciles, quartiles or whichever is estimated convenient in the study. The Histogram map is an empiric approximation to the theoretical distribution of the variable in some sub region. This graphic also allows to detect the presence of spatial heterogeneity, which appears when the regional histogram doesn't present a similar structure to the global histogram; 
additionally, is of great importance to represent the target variable, for determining if it's distribution is normal or not. The dispersion diagram, it allows studying the relationship between two variables, it's a multi-variant technique that consist in a scatter plot for the two variables in which are also represented, in its respective axes the box and whisker plot diagrams of the variables. The Quartiles map, it's a diagram used to identify the distribution of the target variable. In this case, the spatial unities are distributed according with the quartiles of the variable, which way the regions are grouped based on the quintile they belong to. The Cartogram, in this case, each region or spatial unity is replaced by a circle whose area is proportional to the value that the variable assumes in said region. It's a graphic used for the identification of spatial effects, therefore, it allows the identification of regions where the outlier values are. The LISA Map, "Local indicator of spatial association", it's a graphic where those locations with significant values of statistic indicators of local spatial association are represented. These graphics by their definition allow the cluster building and visualization between the regions based in the behavior that the target variable present in each one of them.

\section{Models and special analysis}

The different GIS that are available on the media include libraries or tools (depending on the case) that allow the user the implementation of multiple models, inference techniques and optimization models associated with referenced spatial data. Some of them are described here under.

\section{- Spatial Regression Model}

The analysis of regression is a technique widely used in classical statistic. The efficiency of the results depends on the satisfaction of a set of assumptions, between which the independent behavior of the values that assumes the target variable is found, in this case the data is given a treatment of global character, which means that a stationary spatial behavior of the object variable is assumed. When the supposed independence is not satisfied, in classic statistic, there's a look for implementing re-sampling techniques that allow control over the encountered difficulty, however, it's been noticed that this dependency, can be a signal of the existence of a spatial dependency relationship among the data.

When working with spatial data there are different spatial effects that can be presented that prevent the satisfaction of the assumptions of the classic methods, making these not an ideal tool for the modeling. The spatial effects are: Spatial Dependency \& Spatial heterogeneity.

The Spatial Dependency or spatial autocorrelation is understood as the absence of independence. This leads to everything being related to everything, but those units especially closer will be more related within themselves than the other ones located at a greater distance, obeying that way the first law of Tobler's geography (1970). Therefore, the set of data with registration $\left(y_{i}, x_{i}\right)$, associated to a location $i$, depends on some other observations associated with locations $j \neq i$ through a function, this is; $y_{i}=f\left(y_{j}\right) \quad i=1,2, \ldots n$. This indicates that all the observations in the space of spatial unities are formally related trough the function $f$.

The Spatial Heterogeneity indicates the existence of instability in the behavior of relationships under study, it makes allusion to the variation on the relationships over the space, and this leads to parameters and functional forms that vary with the geographic location. This concept carries to the idea of spatial heteroscedasticity, $\operatorname{Var}\left(\varepsilon_{i}\right)=$ $\sigma_{i^{\prime}}^{2}$ this is, the variance of noise is different in each sample observation unity $i$, in these circumstances the non-stationarity phenomenon would be had. This situation leads to the traditional regression model $y_{i}=\beta_{0}+\sum_{k} \beta_{k} X_{i k}+\varepsilon_{i}$, needing adjustments to a model that considers the non-stationary behavior, these new models, that have a spatial and nonglobal dependency are called spatially pondered regression models. 
The presence of heteroscedasticity and/or auto-correlation in a set of data to be modeled, implies the necessity of defining a matrix of weights and ponderations, conventionally denoted by $W$. This is a square matrix in which it's elements $w_{i j}$ register the intensity of the relationship between the regions $i$ y $j$. These coefficients allow presenting bidirectional and asymmetrical relationships between the different regions in the study. The effect of the spatial dependency of the process is introduced in the classic regression model trough the insertion of this matrix of weights, giving way to the so called pondered spatial regression models. Based on the previously described, the simplest spatial regression model is given by: $y_{i}=\beta_{0}\left(u_{i}, v_{i}\right)+\sum_{k} \beta_{k}\left(u_{i}, v_{i}\right) x_{i k}+\varepsilon_{i}$, where $\left(u_{i}, v_{i}\right)$ denotes the coordinates of the $i$-eth point in the space, and $\beta_{k}\left(u_{i}, v_{i}\right)$ is an execution of the continuous function $\beta_{k}(u, v)$ in the point $i$, these coefficients depend of distance matrix $\mathrm{W}$.

\section{- Bayesian Inference}

While in the classic statistic models the problems of inference and prediction are developed independently, in the Bayesian models an articulated solution for these two problems is found. These aspects make them into a proper alternative to address problems related with geo-referencing.

In general, a geo-statistic model is expressed in two sub-models: a sub-model for a special process not observed denoted by $\left\{S(x): x \in \mathbb{R}^{2}\right\}$, which from now on is going to be called the signal, and a sub-model for the data $Y=\left(Y_{1}, \cdots, Y_{n}\right)$ which are conditioned to the spatial process $S(\bullet)$. For an unknown interest parameter $\theta$ a formal presentation of the model is given by the conditional probability: $[Y, S \mid \theta]=[S \mid \theta][Y \mid S, \theta]$. From the classical theory, the predictive distribution of $\mathrm{S}$ is the conditional distribution $[S \mid Y, \theta]$ that can be obtained through the application of Bayes' theorem. For any objective of $\mathrm{T}$ prediction, that is a determinist function of $\mathrm{S}$, the predictive distribution of $\mathrm{T}$ is immediately followed by S's, being treatable or not (DIGGLE \& RIBEIRO 2007). In any case, in order to generate a relationship between the predictive distribution $[T \mid Y, \theta]$, it's only required generating a relationship from the predictive distribution $[S \mid Y, \theta]$ and applying a deterministic calculation to convert it from $S$ to T. On the other hand, a plug-in prediction simply consists of a training estimated parameter as if they were true; in this case, for any $\mathrm{T}$ objective the plug-in predictive distribution $[T \mid Y, \theta]$. Under these circumstances, is revealed that the Bayesian predictive focus is not concerned about the formal distribution between the not observed random variables $\mathrm{S}$, the signal, and the parameter model $\theta$. The starting point in this case is a joint distribution, hierarchically specified for the three random objects of interest, the data $Y_{i}$, the signal $S_{i}$ and the parameter model $\theta$. For three hierarchic levels, there are: $[Y, S$, $\theta]=[\theta][S \mid \theta][Y \mid S, \theta]$, with $[\theta]$ the main distribution for $\theta$. To ground this concept a little bit there's the hierarchical modeling from the Bayesian focus, based on the previously exposed, it is supported in the fact that the joint distribution is treated as a set of random variables that can be decomposed in a series of conditional models. When complex process are modeled in presence of data, is important for the hierarchical model to be written in three states: E1: Model for the data, E2: Model for the process given the process' parameters. E3: Model for the parameters. In essence, the purpose of the Bayesian focus, is to resolve a problem dividing it into simpler sub-problems.

\section{- The location-allocation model}

The network planning process, in private sector generally consists of designing the system through which services from suppliers flow to demand points; while in the public sector, it consists of determining the set of opened facilities, and establishing how users can be allocated to these facilities.

In general, location-allocation analyses seek to match the best supply (service) locations with demand assigning those demand points to the service facilities, taking into account several constraints. The aim is frequently to identify best $\mathrm{n}$ locations and 
potential sets of locations are evaluated together using an evaluation function of some kind. Typically, this is 'demand weighted distance', the default option in location-allocation tools in the ESRI's ArcGIS, perhaps the leading GIS software, but other evaluation functions have been specified depending on the task in hand. Classic location-allocation models include:

- Add allocation to traditional p-median problem, which minimizes the demand weighted distance (HAKIMI, 1964; REVELLE AND SWAIN, 1970);

- Add allocation to the maximal covering location problem, which seeks to satisfy a distance or travel criterion (CHURCH AND REVELLE, 1974);

- Add allocation to the location set covering problem, which seeks to that minimize the number of facilities to satisfy some demand coverage (TOREGAS ET AL. 1971).

Other element key in the modeling of locationallocation is the customer goes to the service or the service goes to customer (BOSQUE AND FRANCO, 1995). These approaches and their variants (SEE OWEN AND DASKIN 1998) for a comprehensive review - have been used to consider a number of different types of geographical problems related to facility siting and accessibility. Typical applications include where to site new facilities (E.G. SASAKI et al., 2011), where to enhance capacity in existing facilities (E.G SASAKI et al., 2010), to determine which facilities to close (E.G. COMBER et al, 2009) and where to locate new facilities (E.G. COMBER et al., 2011). They are used to suggest facility locations, to identify gaps in service provision and to highlight geographic regions with low service coverage.

Finally, consider only the location, facilities are divided in two groups, the first one are desirable to the nearby inhabitants which try to have them as close as possible such as hospitals, fire stations, shopping stores and educational centers. The second group turns out to be undesirable for the surrounding population, which avoids them and tries to stay away from them such as garbage dumpsites, chemical plants, nuclear reactors, military installations, prisons and polluting plants. In this sense, Daskin (1995) discussed that Erkut (1995) distinguished between Noxious (hazardous to health) and Obnoxious (nuisance to lifestyle) facilities, although both can be simply regarded as Undesirable. But Latin-American do not produce nuclear energy, the obnoxious facilities are no consider in these applications.

Location-allocation models generally are NP problem, then apply search heuristic or metaheuristic for real problem rather than deterministic algorithm is usual. This is because very simple location-allocation problems are highly dimensional and it would simply take too long to evaluate every set of potential locations. Classic search heuristics include the Teitz and Bart search heuristic (1968), genetic algorithms (GOLDBERG, 1989; HOLLAND, 1975) and grouping genetic algorithms (FALKENAUER, 1998; COMBER et al., 2011). Each of these converges on the optimal set of $\mathrm{n}$ locations without having to evaluate every possible set of $n$. The reason for avoiding deterministic solutions is illustrated by a simple example: consider a problem where the objective is to identify the best 35 facilities in a study area comprising a 100 by 100 grid (for example of $1 \mathrm{~km}^{2}$ ) of potential locations. The feasible space has approx. $9.12 \times 1099$ members. Report and papers as Comber (2015), Melo (2017) and Zhao (2017) taking in account some of those features describe here.

\section{The optimal localization -} assignation models

There are different kinds of localization assignation models which depend on the character or nature of the service. Some of these classes are:

P-Medium Model, seeks to minimize the amount of the population displacement products of the demand points (Centers that group the dispersed demand) to the offer points. The objective function is Minimize $\left\{F=\sum_{i=1}^{n} \sum_{j=1}^{n} a_{i} d_{i j} x_{i j}\right\}$.

Revista EIA Rev.EIA.Esc.Ing.Antioq / Universidad EIA 
Where $a_{i}$ is the associated weight to each demand point, $d_{i j}$ the distance between the demand point $i$ and the potential offer point, $j, x_{i j}$ is the assignation factor, it assumes the value of 1 if the offer center $j$ is the closest to the demand point $i$, and 0 in the opposite case $n$ is the total quantity of demand point and $m$ the potential offer points. Maximum coverage model, its objective is to maximize the total values of the demand inside a coverage radium $(R)$, which has been prefixed to the offer points. It's expected that in these surfaces the maximum demand quantity is assigned; the objective function is. Maximize $\left\{F=\sum_{i \in I} a_{i} x_{i}\right\}$, where, I is the set of demand points (indexed by $i$ ), $a_{i}$ the population in the demand node $i$, and $x_{i}$ is worth 1 if the demand center $i$ is located inside the coverage area $\left(x_{i} \leq R\right)$ and 0 in the opposite case. Maximum coverage model with remoteness restriction, has as purpose maximizing the total values of the demand inside a prefixed coverage radius for the offer points, before applying, a remoteness restriction must be added, this is only possible if the whole demand inside a radius $S$ is considered, bigger than the service's or good's reach. There are some other kind of localization - assignation models that are also utilized, such as the Maximin and Maxisum, used for installation equipment that are non-desirable.

Finally, we're going to talk about the distance between the demand points and the offer points $\left(d_{i j}\right)$, this is, the distance from the center of the areas with grouped demand to the existing facilities or to the candidate points. These distances are frequently demanded in the solution and approach of these problems due to the importance involving the process. In essence, we work with three different distances, which are calculated based on the coordinates of each location. The Euclidean distance, it's applied when you have an ideal space where there's no limitations to transit within, it's given by: $d_{i j}=\sqrt{\left(x_{i}-x_{i}\right)^{2}-\left(y_{i}-y_{i}\right)^{2}}$. The Manhattan distance or city block, assumed by a displacement through a regular grid it's given by: $d_{i j}=\left|x_{i}-x_{i}\right|-$ $\left|y_{i}-y_{i}\right|$. The $L p$ metric, defined by: $d_{i j}^{\beta}=\left(\left|x_{i}-x_{i}\right| P_{-}\right.$ $\left.\left|y_{i}-y_{i}\right|\right|^{P / p}$ is appropriate for those problems of localization in which blocks or barrier appear or there is an over estimation based on the apparition of streets in different directions of the square grid of basic circulation, or obstacles on the space. Note that here there's a parameter $\beta$ that indicates a modification of the displacement costs with the distance, this distance can be seen as well as a general case of the other two.

\section{APPLICATION OF THE GIS TOOLS IN THE PLANNING OF THE ELECTRICAL \\ NETWORKS}

The experience in the use of the GIS tools by different planning departments of the electricity distribution utilities in Latin American cities shows that the information obtained with the use of these tools can help in the decision making for the planning of the distribution networks, as will be explained in this section.

For example, the purchase of electrical appliances with high electric consumption is one of the factors that generate changes with great impact in the residential electrical demand. This purchase can be stimulated by political decisions of governments, as is the case of the Republic of Ecuador which initiated an incentive program to reduce the consumption of liquefied petroleum gas (LPG), motivating the residential sector to use induction stoves. Due to several factors, such as: price of the product, cost of installation and maintenance, etc. Therefore, the install these stoves is not interesting to for all habitants of the residential sector. The use of GIS tools is important because it is a great challenge for planners to determine the regions where the installation of these electrical appliances will affect the system. Determine the impact that will be caused by these electrical appliances, is very important to be able to make the necessary adjustments in the electrical network. 
The spatial analysis libraries available in the GIS tools allow the use of socioeconomic variables typical of a region to determine the behavior of a variable of interest. Additionally, the results obtained can be presented through thematic maps to visualize their spatial distribution.

In the Figure 1, shows the results obtained by Mejia (2017) in a market potential analysis that was performed using GIS tools to determine the sectors with the highest proportion of residences interested for buying induction stoves in an Ecuadorian city, and thus, determine the impact on the electricity distribution network. The heterogeneous distribution of these obtained results is because not all areas of the city are residential (which will be the most impacted because of the installation of the stoves); there are also commercial, industrial, and vegetation areas. In addition, there will be residential sectors for which, according to their socioeconomic characteristics, it is not interesting or it is not economically feasible to buy the electric appliance.

The identification of the regions most interested in buying the electric appliance allows system planners to locate where load growth will occur, and thus, make the necessary adjustments in the system so that it can fulfill with future energy requirements. In the Figure 1, we observe that not all the electrical network will be impacted in the same way, there are sectors that need to transfer loads between the transformers, other sectors where it necessary to potentiate the circuit (transformers and distribution lines), and sectors where must to build new feeders to supply the energy demanded by consumers. In addition, in the work developed by Mejia (2017), a library of GIS tools was customized to model the spatial distribution of the temporal growth of that proportion of candidate residences to buy induction stoves. The results are shown in Figures 2 to 4 .

In the Figures 2 to $\mathbf{4}$, it can be observed that there are sectors with a higher rate of growth of installation of stoves than others (faster temporal growth), these sectors need more attention from the network planners, because in these sectors will increase load in less time and they must be intervened as soon as possible.

The importance of the results obtained is that they allow making a future projection of what will happen in the network over time. Normally, the construction of new distribution feeders and substations of energy transformation, are works that take years to be able to be in point of operation. Having a spatial-time forecast of the growth of the load, allows making the necessary adjustments in the distribution network of energy, with sufficient time of antecedence.

\section{Figure 1. Proportion of residences candidates to buy induction stoves}

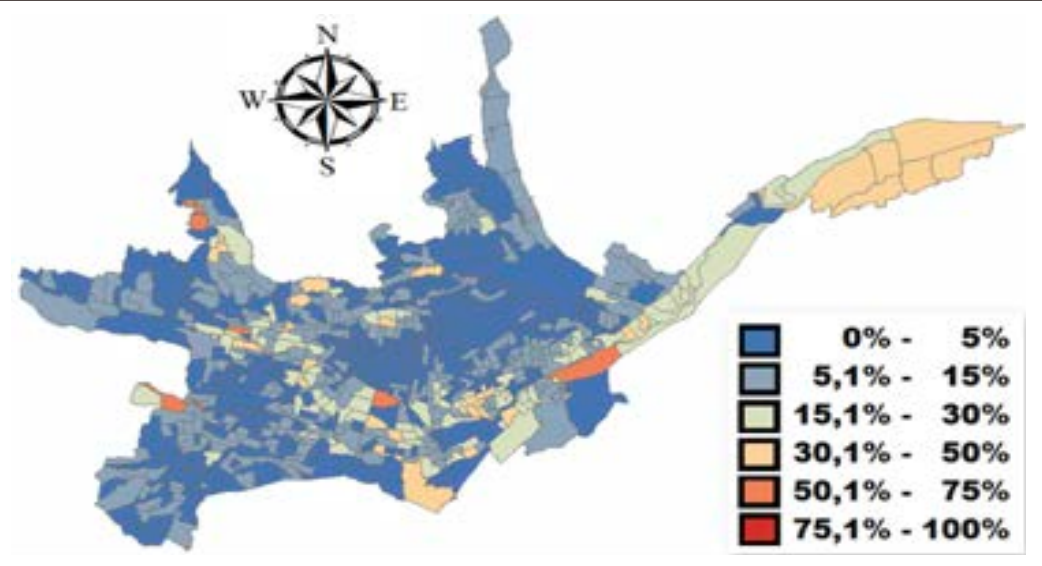


Figure 2. Proportion of residences candidates to buy induction stoves. Year_1

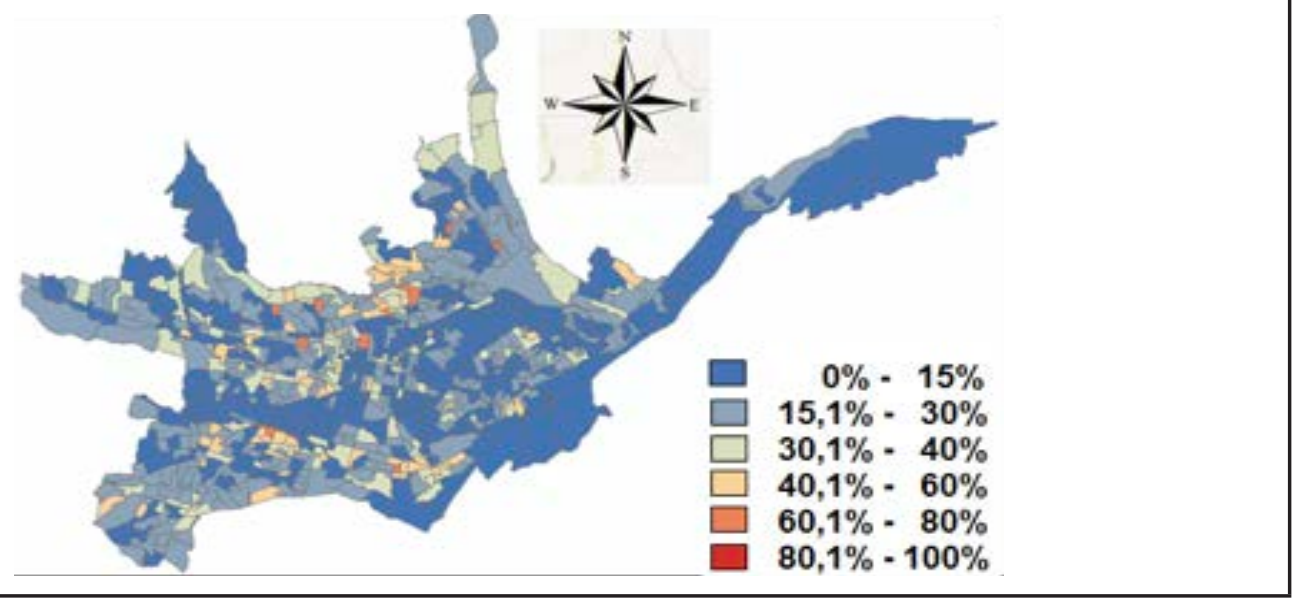

Figure 3. Proportion of residences candidates to buy induction stoves. Year_2

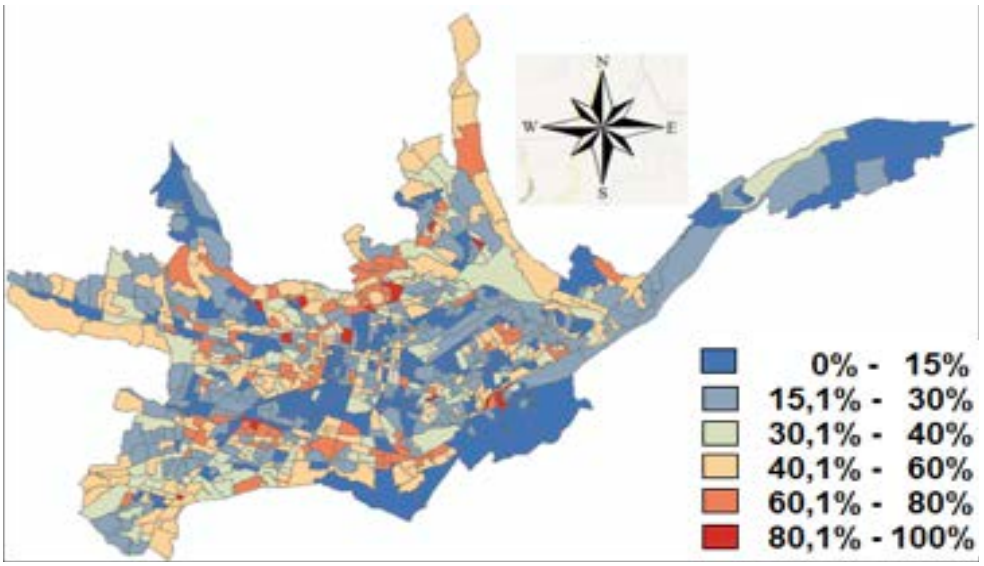

Figure 4. Proportion of residences candidates to buy induction stoves. Year_2

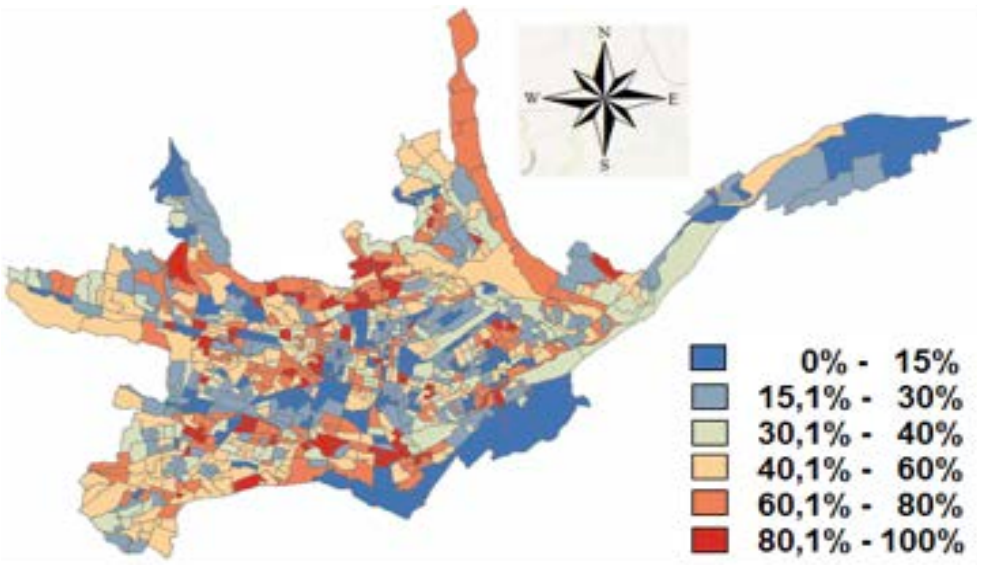


On the other hand, in the urban zone of cities with high values of solar incidence, the installation of solar panels is being promoted. These panels can partially meet consumers' electrical demand. However, because of the high prices of the installation of these solar panels, delay in the economic return for the investment made, insecurity in this new technology and little information on the advantages of using photovoltaic solar energy, are factors that make some consumers have little interest in the installation of this type of technology. Depending on the socio economic characteristics of the city, the installation of solar panels will only have impact in some regions, as was shown in the study conducted by Villavicencio (2016), which used GIS tools to determine the photovoltaic potential of a Brazilian city, due to the installation of photovoltaic systems on the roofs of the residential area. The Figure 5 presents the results obtained by Villavicencio (2016), in which he considered: the level of solar irradiation, the area available on the roofs for the installation of photovoltaic systems and the conversion efficiency of these photovoltaic systems.

Figure 5. Thematic map of the photovoltaic potential (kW) of a Brazilian city, considering the probability of installation of photovoltaic systems

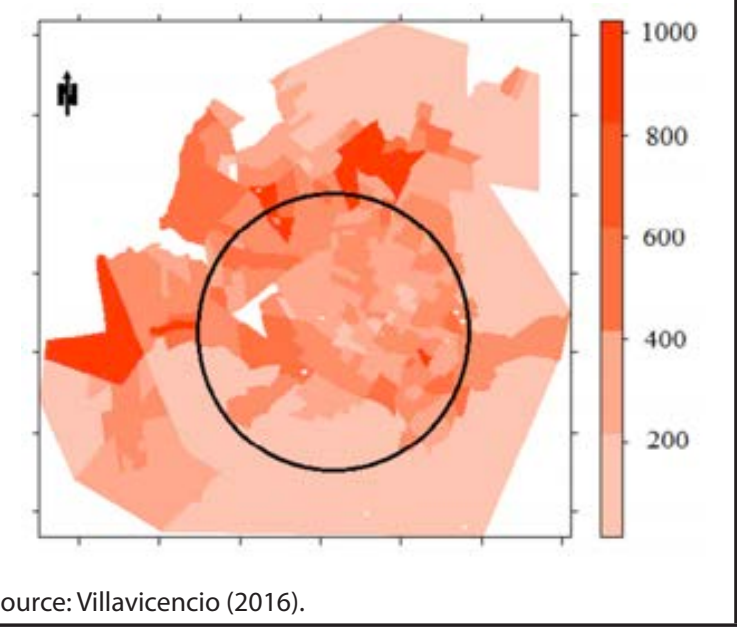

Additionally, in Villavicencio (2016), a library of GIS tools was customized to allow the use of socioeconomic characteristics of the population, and consider the preferences of the habitants in the installation of new technologies to determine a new photovoltaic potential of the city considering probabilities of installing solar panels on the roofs of the residential area. The results obtained are shown in Figure 6.

Figure 6. Thematic map of the photovoltaic potential (kW) of a Brazilian city, without considering installation probabilities of photovoltaic systems

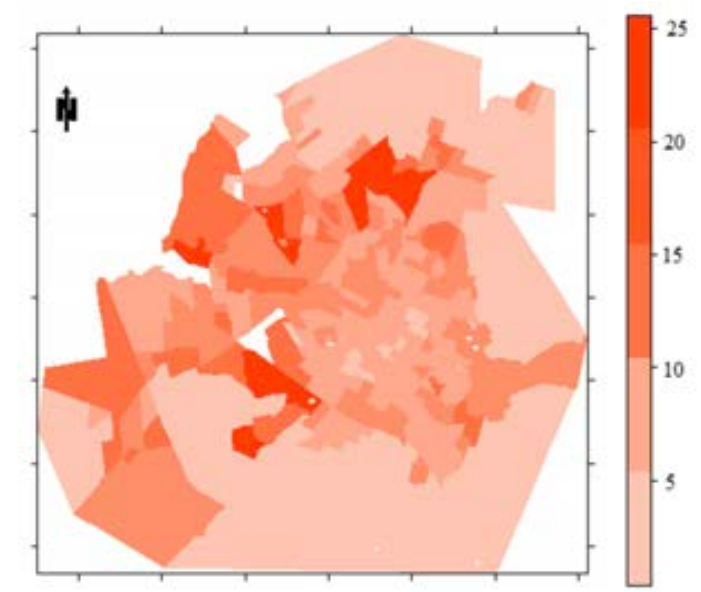

Source: Villavicencio (2016).

In the Figure 6, it can be observed that despite the fact that various incentives are offered to motivate the use of photovoltaic solar energy, few regions where their inhabitants are interested in installing photovoltaic panels in their residences. This type of maps helps planners to observe regions with greater potential of interest in the installation of photovoltaic panels, and thus, to verify if any changes in the way of operating the distribution network will be necessary because that the hours of higher generation of photovoltaic energy are when consumers are not in their homes, resulting in higher voltage levels in the networks, if the power distribution system do not have the right controllers. This was demonstrated in the work developed by Quiros-Tortos, Valverde, Argüello, and Ochoa (2017), who used GIS tools to locate affected networks sectors due to the installation of photovoltaic panels in a Costa Rican city. The results presented in Figure 7 , show the location of the system nodes that are with voltage levels above the allowed limit. 


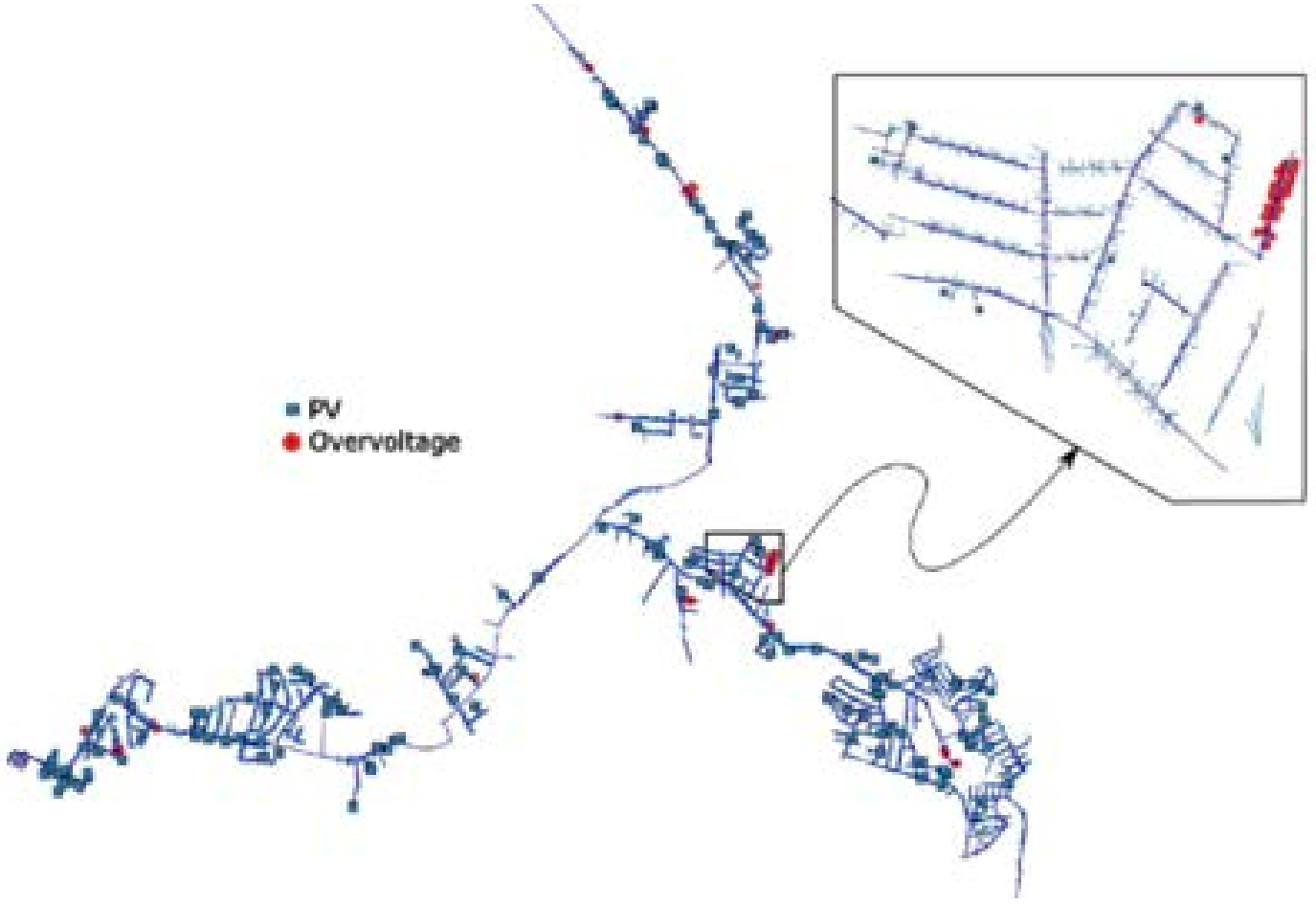

\section{DISCUSSION}

Despite the great utility of used of GIS tools, there are still a number of difficulties in some planning departments. Most of these difficulties are associated with the investment needed to integrate information from the various departments of the company. In general, the computational tools with geo-referenced information have been used in the surveying areas for the registration of the company's assets.

Another difficulty encountered is the lack of training of personnel of the department of planning for the spatial database. Some companies only use the GIS tools to create maps, however, data analysis and optimization techniques that the GIS tools contain, are little used. Although, these tools need to be updated for the needs of the electrical network planning, we can be observed that some utilities are interested in this type of tools because they do not have an integration with the other tools that are used in day-to-day tasks. For example, commercial software that is used to perform power flow does not consider the geographical coordinates of consumers or electrical installations. Therefore, in order to make GIS more useful in planning studies, new GIS libraries that complement the computational tools used in the planning department should be considered.

\section{REFERENCES}

\section{Books}

DIGGLE, P. and RIBEIRO, P. J. Model - based Geostatistics. Springer Series in Statistics. Editorial Springer., New York, 2007.

FOTHERINGHAM, A. S.; BRUNSDON, C. and CHARLTON M. Geographically Weighted Regression. The analysis of spatially varying relationships. Editorial WILEY, England, 2002.

GONEN, T. Electric power distribution system engineering. Boca Raton: CRC Press, 2014.

KAGAN, N. Redes elétricas inteligentes no Brasil: análise de custos e benefícios de um plano nacional de implan- 
tação. Rio de Janeiro: Synergia Editora, 2013. 260 pag.

GUTIERREZ, J. and GOULD, M. SIG: Sistemas de Información Geográfica. Editorial Síntesis S.A., Madrid, 1994.

CAMARA, G. E. A. Mapping Social Exclusion/Inclusion in Developing Countries: social Dynamics of São Paulo in th 1990s. In: GOODCHILD, M. F.; JANELLE, D. G. Spatially integrated social science. New York: : Oxford University Press, 2004. Cap. 11, p. 223-237.

MIRANDA, J. I. Fundamentos de sistemas de informações geográficas. 4a. ed. [S.I.]: [s.n.], 2015.

SILVA, A. D. B. Sistemas de informações geo-referenciadas: conceitos e fundamentos. [S.l.]: [s.n.], 2003.

SILVA LORA, E. E. e ADDAD, J. Geração distribuída: aspectos tecnológicos, ambientais e institucionais. Rio de Janeiro: Inter ciência, 2006.

\section{Dissertations}

MEJIA ALZATE, M. Previsão Espaço-temporal de demanda incluindo alterações nos hábitos de consumidores residenciais. Disertação de Mestrado. Universidade Estadual Paulista. Faculdade de Engenharia de Ilha Solteira. Ilha Solteira, p. 78. 2017. Disponível em: <http://hdl.handle.net/11449/148538>

VILLAVICENCIO GASTELU, J. Análise Espacial do potencial fotovoltaico em telhados de residência usando modelagem hierárquica bayesiana. Disertação de Mestrado. Universidade Estadual Paulista. Faculdade de Engenharia de Ilha Solteira. Ilha Solteira, p. 101. 2016. Disponível em: <http://hdl.handle. net/11449/137801>.

\section{Articles}

ACEVEDO, I. y VELÁSQUEZ, E. "Algunos conceptos de la econometría espacial y el análisis exploratorio de datos espaciales". Ecos de Economía. Num 27. Medellín, Colombia 2008. Disponible en: <http://publicaciones.eafit.edu.co/index.php/ecos-economia/ article/viewFile/705/627>

ARANEDA E. “Uso de Sistemas de Información Geográficos y análisis espacial en arqueología: Proyecciones y limitaciones". Estudios Atacameños. Num. 22, pag. 5975 Santiago, Chile 2002. Disponible en: < http://dx. doi.org/10.4067/S0718-10432002002200004 >

BUZAI, G. D. “Modelos de localización-asignación aplicados a servicios públicos urbanos: análisis espacial de Centros de Atención Primaria de Salud (caps) en la ciudad de Luján, Argentina”. Cuadernos de geografía: revista colombiana de geografía. Vol. 20, Num. 2, pag. 111 - 123 Bogotá, 2011.

COMBER, A. J.; BRUNSDON, C.; HARDY, J. and RADBURN, R. "Using a GIS-based network analysis and optimisation routines to evaluate service provision: a case study of the UK". Post Office Applied Spatial Analysis and Policy. Vol. 2, Num. 1, pag. 47 - 64, 2009.

COMBER, A.; DICKIE, J.; JARVIS, C.; PHILLIPS, M. and TANSEY, K. "Locating bioenergy facilities using a modified GIS-based location-allocation-algorithm: considering the spatial distribution of resource supply, unpublishing submitted paper". Department of Geography, University of Leicester, Leicester, LE1 7RH, UK (2015) Availavel in: <https://lra.le.ac.uk/ bitstream/2381/32346/4/Comber_AE_submission_March_2015.pdf.>

COMBER, A. J.; SASAKI, S.; SUZUKI, H. and BRUNSDON, C. "A modified grouping genetic algorithm to select ambulance site locations". International Journal of Geographical Information Science, Vol. 25, Num. 5, pag. 807 - 823, 2011.

CHURCH, R. and REVELLE, C. "The maximal covering location problem". Papers in Regional Science, Vol. 32, Num. 1, pag. 101 - 118, 1974.

HAKIMI, S. "Optimum Locations of Switching Centers and the Absolute Centers and Medians of a Graph". Operations Research, Vol. 12, pag. 450 - 459, 1964.

HAMMONS, T. J. "Renewable energy alternatives for developed countries". IEEE Transactions on Energy Conversion, Piscataway, Vol. 15, Num. 4, pag. 481-493, 2000.

HO, C. and K. C. "Impact of grid-connected residential PV systems on the Malaysia low voltage distribution network". IEEE conference, Power engineering and optimization, Langkawi Island, Malaysia. pag. 670 675. , 2013.

LEOU, R. C.; TENG, J. H. and SU, C. L. "Modelling and verifying the load behaviour of electric vehicle charging stations based on field measurements". IET Generation, Transmission \& Distribution, Vol. 9, Num. 11, pag. 1112 - 1119, August 2015.

MEJIA, M. A.; MELO, J. D.; ZAMBRANO-ASANZA, S. e FELTRIN, A. P. "Regressão Ponderada Geograficamente para estimar a distribuição espacial do potencial de mercado de um eletrodoméstico com alto consumo 
de energia elétrica". Congresso Brasilero de Automatica [S.l.]: CBA. 2016.

MELO, J. D.; ZAMBRANO-ASANZA, S. and PADILHA-FELTRIN, A. "A local search algorithm to allocate loads predicted by spatial load forecasting studies". Electric Power System Research, Vol. 146, pag. 206-217, May 2017.

OWEN, S. H., AND DASKIN, M. S. "Strategic facility location: A review". European Journal of Operational Research, Vol. 111. Num. 3, pag. 423 - 447, 1998.

QUIROS-TORTOS, J.; VALVERDE, G.; ARGÜELLO, A. and OCHOA, L. N. "Geo-Information Is Power: Using Geographical Information Systems to Assess Rooftop Photovoltaics in Costa Rica". IEEE Power and Energy Magazine, Vol. 15, Num. 2, pag. 48 - 56, March 2017. Available in: https://www.researchgate.net/publication/314200428_Geo-Information_Is_Power_ Using_Geographical_Information_Systems_to_Assess_Rooftop_Photovoltaics_in_Costa_Rica

REVELLE, C. S. and SWAIN, R. W. "Central facilities location”. Geographic Analysis, Vol. 2, pag. 30 - 42, 1970.

RUBIO BARROSO, A. y GUTIERREZ, J. "Los Sistemas de Información Geográficos: Origen y perspectivas”. Revista General de Información y Documentación, Vol. 7, Num. 1. Servicio de Publicaciones Universidad Complutense. Madrid. 1997 Disponible en: http:// revistas.ucm.es/index.php/RGID/article/viewFile/ RGID9797120093A/10990

SASAKI, S.; COMBER, A. J.; SUZUKI, H. and BRUNSDON, C. "Using genetic algorithms to optimise current and future health planning - the example of ambulance locations". International Journal of Health Geographics, Vol. 9, pag. 4 - 12, 2010.

Availavel in < doi:10.1186/1476-072X-9-4>

SASAKI, S.; IGARASHI, K.; FUJINO, Y.; COMBER, A. J.; BRUNSDON, C.; MULEYA, C. M. and SUZUKI, H. "The impact of community-based outreach immunization services on immunization coverage with GIS network accessibility analysis in peri-urban areas, Zambia". Journal of Epidemiology and Community Health, Vol 65, pag. 1171-1178, 2011.

Availavel in <doi:10.1136/jech.2009.104190>

SHU, J. A new method for spatial power network planning in complicated environments. IEEE Transactions on Power Systems, Vol. 27, Num. 1, pag. 381-389, Feb. 2012.
VILLAVICENCIO, J.; MELO, J. D. and FELTRIN, A. P. "Estimation of photovoltaic potential on residential rooftops using empirical Bayesian estimator". IEEE PES Innovation Smart Grid Technologies Latin America ISGT LATAM. [S.I.]: IEEE. 2015.

WATSON, J. D. "Impact of solar photovoltaics on the lowvoltage distribution network in New Zealand". IET Generation, Transmission \& Distribution, Stevenage, Vol. 10, Num. 1, pag. 1-9, 2016.

WEI, W. "Expansion Planning of Urban Electrified Transportation Networks: A Mixed-Integer Convex Programming Approach". IEEE Transactions on Transportation Electrification, Vol. 3, Num. 1, pag. 210 - 224, March 2017.

ZAHEDI, A. "Australian renewable energy progress". Renewable and Sustainable Energy Reviews, Oxford, Vol. 14, Num. 8, pag. 2208-2213, 2010.

\section{Websites}

RENEWABLES 2015 GLOBAL STATUS REPORT. Renewable energy policy network for the 21th century (REN21), 2015. Disponível em :

<http://www.nrel.gov/docs/fy08osti/42306.pdf>. Acesso em: 10 jun. 2017.

\section{PARA CITAR ESTE ARTÍCULO / TO REFERENCE THIS ARTICLE / PARA CITAR ESTE ARTIGO /}

Mejía Alzate, M.A.; Melo Trujillo, J.D.; Padilha Feltrin, A.; Sánchez Zuleta, C.C.; Fernández Gutiérrez, J.P. (2018). Geographical Information Systems as a Tool to Assist the Electricity Distribution Networks Planning. Revista EIA, 15(29), enero-junio, pp. 71-85. [Online]. Disponible en: https://doi.org/10.24050/reia.v15i29.1138 